\title{
Portuguese Psychology: Placing the Professional Practice and Training in a Global Context
}

\section{Psicología Portuguesa: Situando la Práctica Profesional y la Formación en un Contexto Global}

\author{
Vitor Alexandre Coelho** \\ Gabinete de Estudos, Ordem dos Psicólogos \\ Portugueses, Portugal \\ Marta Marchante \\ Gabinete de Estudos, Ordem dos Psicólogos \\ Portugueses, Portugal \\ Patrícia Brás \\ Gabinete de Estudos, Ordem dos Psicólogos \\ Portugueses, Portugal \\ Liliana Pereira \\ Gabinete de Estudos, Ordem dos Psicólogos \\ Portugueses, Portugal
}

\footnotetext{
**Email:

victorpcoelho@gmail.com;

observatorio@ordemdopsicologos.pt
}

\begin{abstract}
Presently, the profession of psychologists has evolved greatly since the first psychology degree was created in 80 's; however, in Portugal studies concerning the profession of psychologists are scarce. So there is a need to describe the situation of psychologists in Portugal, as well as to predict and comparing it with other countries in order to influence political and professional decisions regarding the practice. In this study official data from Government sources and from the professional national association (Order of Portuguese Psychologist) was collected. The sample consisted of 14140 psychologists, 85\% females, and average age was 39. The results showed a great expansion both in academic and professional numbers: there are psychologists working in a wide spread of areas and locations.
\end{abstract}

\section{Keywords}

professional practice, Portugal, international comparisons.

\section{RESUMEN}

En la actualidad, la profesión de psicólogo ha evolucionado mucho desde que ha sido creado el primer grado universitario de psicología en los años 80. Pero, sin embargo, en Portugal los estudios relativos a la profesión de psicólogos son reducidos. Entonces, es necesario describir la situación de los psicólogos en Portugal, así como compararla con otros países para influir en las decisiones políticas y profesionales relativas a la práctica. En este estudio se recogieron datos oficiales de fuentes gubernamentales y de la asociación profesional nacional. La muestra consistió en 14.140 psicólogos, 85\% mujeres, y la edad media fue de 39 años. Los resultados mostraron una gran expansión tanto en el ámbito académico como profesional: hay psicólogos que trabajan en una amplia gama de áreas y lugares. 
Vitor Alexandre Coelho, Marta Marchante, Patrícia Brás, Liliana Pereira.

Palabras clave

Práctica professional, Portugal, comparaciones internacionals.

How to cite: Coelho, V. A., Marchante, M., Brás, P., \& Pereira, L. (2016). Portuguese psychology: Placing the professional practice and training in a global context. Universitas Psychologica, 15 (4). http://dx.doi.org/10.11144/Javeriana.upsy15 -4.pppp

Psychology in Portugal has been experiencing challenging times. Since 1975, when 3 license degrees were established, there has not been a period of great expansion, garnering more attention than ever before, with psychologists taking on additional roles un society. There are now psychologisys contributing in diverse areas: working in health, education, organizations, social security system, the justice system, sports, among others (Coelho, Brás, \& Sousa, 2011). The number of people who hold a license degree in psychology has risen sharply, as the number of universities who offer studies in Psychology (Coelho et al., 2011). This development has generated some debate about if this expansion has been a period of consolidation or a simple growth in numbers.

A study conducted at the beginning of the previous decade (Coelho \& Ribeiro, 2001) identified that the first licensed degree holders in Psychology finished their studies in 1980. The next decade was marked by a slow increase in the number of graduates in Psychology. However, during the nineties there was a sharp increase in the number of people who held psychology degrees; during the period comprised between 1996 and 2000 there was $103 \%$ increase, reaching 7633 psychology degree holders. There are indications that the growth in the last decade even surpasses the growth identified in 1995-2000.

However, this development in the profession in the last 15 years has not been accompanied by studies that appropriately describe and characterize the scope of this growth. There is a lack of analysis that would allow mapping out the future development of the profession, as well as helping to structure the path for future inclusion of master's degree holders into the professional world. Practitioners, students, and prospective future students of Psychology should have information available to allow them a responsible decision-making process.

There is also a need to analyze the current unemployment numbers in Portugal, given that psychology is constantly presented as a profession with one of the highest unemployment rates among university graduates (Cardoso, Varanda, Madruga, Escária, \& Ferreira, 2012). As such, it is imperative to understand what the main areas in which psychologists work, and also to know which areas have a higher percentage of psychology professionals.

It is also important to situate this development of psychology in Portugal within the European and World levels. All around the world, there are countries where psychology has been developing as a science and a practice for much longer than Portugal. In the United States, the world's leading psychology association founded in 1892 (American Psychological Association [APA]) congregates 88000 individual licensed psychologists (APA, 2014a), while in the United Kingdom there has been a professional association (the British Psychological Society) representing the class since 1901 .

Since Portugal is a member of the European Union, there is a need to analyze the recent developments of the profession in Europe, especially Southern Europe. Presently, there are common challenges brought by the Bologna process (that standardizes university degrees in the countries of the European Union), and by the increased mobility between European countries supposedly offered by the European Diploma of Psychology (European Federation Psychologists' Associations, [EFPA], 2013b). These circumstances have led to increased links between the various European countries. Furthermore, the professional situation of psychologists in Portugal within this context should be subject to additional attention since the European Federation of Psychologists' Associations represents indirectly 260000 psychologists in 35 countries (EFPA, 2013a), 
and these numbers would place Portugal presently as one of the countries with a higher ratio of psychologists in the population (1.5 psychologists per 1000 inhabitants).

The specificity of Portugal is further notorious when seen in contrast with most countries. The APA's Center for Workforce Studies (2014) estimates that there are 93000 practicing psychologists in the United States of America, which would place the ratio at one psychologist per each 3333 inhabitants (308,745,538 inhabitants reported by the US Census Bureau, 2010) with graduations averaging 4000-5000 per year, in a system encompassing 444 doctoral departments who offer degrees in Psychology (Wicherski, Hamp, Christidis, \& Stamm, 2014).

The biggest country in the European Union is Germany (with 80.5 million inhabitants) having 52867 (Roe \& Freeman, 2011) psychologists, and 44 universities offering university training in Psychology, in which around 30000 students are enrolled (Spinath \& Stehle, 2010). In the United Kingdom, the British Psychological Society has 42100 active members (1 psychologist per 1522 inhabitants), according to EFPA (2013b), and 115 undergraduate courses in Psychology (Trapp \& Reddy, 2010), with 4000 students studying Psychology at a masters or doctoral level (Trapp \& Reddy, 2010).

A country with a population similar to Portugal is Belgium (around 11 million inhabitants) who has 7 universities offering university training in Psychology and 7254 practicing psychologists, as reported by the Belgian Psychologist Commission (2011); this means that there is one active psychologist per 1538 inhabitants. Probably the most relevant European country to analyze is Spain, as it has many similarities to Portugal, in general, but also in its late development of the profession of psychology (the professional association, Colegio Oficial de Psicólogos, was created in 1979). Presently, Spain has 56053 active psychologists (EFPA, 2013b), which places the ratio of psychologist per inhabitant in 1/831, the lowest among analyzed countries. Spain possesses 30 universities presently providing university studies in Psychology (AparicioGarcía \& Sánchez-López, 2010); concomitantly Hernández (2003), reports a very high number of psychology students in 2002/2003 (57111).

It is vital to mention the rapid growth in the number of active psychologist in Spain since 1980. Santolaya, Berdullas, and Fernández (2001) report that there were 2358 psychologists in 1980, but in 1984 there were already 11403 (a fourfold increase), this increase was noticeable in 1988 when there were 17261 psychologists. During the 1990's the rate of growth was also quite intensive (62\%) until 1999 (28000 psychologists). The present number of 56000 psychologists indicates that from 1999 to 2013, the number of psychologist doubled.

The distribution of psychologists per area of practice is also very disparate among different countries, even though there is always a predominance of psychologists who work in Health and Clinical Psychology (68.4\% in Spain and $55 \%$ in Germany). The disparity of working fields can be exemplified when analyzing the place of Educational Psychology in Spain and Germany: in Spain it is the 2nd most important field of practice (with $15.3 \%$ of psychologists practicing in it), while in Germany it is only the 5th (with just $4 \%$ of psychologists). The same applies for teaching and research which is responsible for $15 \%$ of practice in Germany, but only $0.5 \%$ in Spain. Similarly, in Forensic Psychology, Germany only has 5\% of practitioners, while Spain only reports $1.2 \%$.

An area where there are some similarities is the area of Organizational Psychology (as well as Social and Community Psychology), which represents $12.5 \%$ of Spanish Psychologists while in Germany it accounts for $19 \%$ of practitioners (Santolaya et al., 2001; Spinath \& Stehle, 2010).

Outside Europe, namely in the United States of America, the scenario is closer to the German distribution: with $41.3 \%$ of APA members working in health and clinical Psychology, 2.6\% in the school context, $11.9 \%$ in research, and only $0.7 \%$ in the forensic context (APA, 2014b).

Concerning gender there are also some differences between countries, for example, in Spain there are $72.6 \%$ female psychologists 
while in United States this percentage is lower, only $57.7 \%$ of psychologists are female (APA, 2014b; Santolaya et al., 2001). Similarly, the psychologists from these two countries differ in another characteristic, the mean age in United States is quite higher: 55.4; $\mathrm{SD}=15.4$ (APA, 2014b), on the other extreme it is in Spain that psychologists are younger with a mean age of 36.5, $\mathrm{SD}=8.14$ (Santolaya et al., 2001).

Therefore, the purposes of this study are: a) to describe the growth in the number of psychologists, b) and psychology degrees in Portugal; c) situate the professional situation in Portugal in a global context allowing for comparisons; d) supply credible studies to contribute to the political debate about professional organization of psychologists in Portugal; and e) establish a base for predicting future developments of the professional situation of psychologists in Portugal for the next years.

\section{Method}

\section{Procedure}

Information was gathered from official data regarding students, provided by the Ministry of Science and Higher Learning and aggregated with four different studies. These were conducted in December 2000, December 2004, December 2007, and December 2010, in which all Universities and Institutes that have a license degree in Psychology accredited by the Portuguese Ministry for Science and Higher Learning received a questionnaire containing questions concerning the number of students and license degrees issued. In the first, second, and third studies, 23, 32, and 37 universities (respectively) returned totally filled questionnaires. In the fourth study only 32 out of $34(94 \%)$ institutions responded to the questionnaires sent. For the remaining institutions data was obtained from official publications from the Ministry of Science and Higher Learning.

Further data was collected from the registries into the Order of Portuguese
Psychologists; data was collected in May 2011. The registration process required candidates to supply information regarding professional areas of practice. The information was then coded by five psychologists. For validity purposes, all data was cross referenced with available data provided by official sources. Actualized data concerning personal characteristics of psychologists, their employment and unemployment rates, were gathered in October 2012.

\section{Participants}

The number of participants of the study is 14140 (10662 of which corresponds to the number of candidates accepted as full psychologists up to May 2011), and as such there was total registry information available. $85 \%$ of the sample was female and average age was $39.0(\mathrm{SD}=8.46)$.

\section{Instruments}

University information form (Associação Nacional de Estudantes de Psicologia, 2000) A form containing 7 questions regarding the present number of psychology students, as well the number of past graduates in Psychology.

Order of Portuguese Psychologists registration form. This form is a self-report questionnaire (completed at the time of registration) mandatory for all who wish to be registered into the Order of Portuguese Psychologists. This registration form collects personal information such as age, gender, and address, academic data such as university, degree, and graduation date, and professional data comprising present workplace and previous professional experience. 


\section{Results}

\section{Number and Geographical Distribution of Portuguese Psychologists}

Even though the professional association of Psychologists is quite recent (2008), it is possible to notice that there is a high percentage of inactive psychologists $(3885 ; 19.5 \%)$, when compared with the 14140 active members. The main reason for inactivity is the number of unemployed psychologists $(3682 ; 18.5 \%)$.

The distribution of psychologists by delegation resembles the distribution of population in Portugal. However, almost half of Portuguese psychologists work in the South (47.5\%), even though it is the North of Portugal which is the most populous area of the country. The northern part of the country is the second higher in number of psychologists $(32.7 \%)$, followed by the central region $(15.7 \%)$. The autonomous region of the Azores (2.2\%) has slightly more psychologists than the autonomous region of Madeira (1.9\%).

\section{Distribution by Fields}

As it can be seen in Table 1, more than half of the psychologists claimed to work in the area of Clinical \& Health Psychology $(51.7 \%)$ and about a quarter claimed to work as an Educational Psychologist (21.6\%). Work \& Organizational and Social \& Community Psychology are responsible each for around $10 \%$ of practitioners. In all areas there is a high predominance of female psychologists, with percentages higher than $80 \%$, except for Sports Psychology, where almost two thirds (65.2\%) of psychologist are male.
Table 1

Number and percentage of Psychologists

Working in each Field and Information by Gender

\begin{tabular}{|c|c|c|c|c|}
\hline Fields of Psychology & $N$ & $\%$ & $\begin{array}{l}\text { Female } \\
(\%)\end{array}$ & $\begin{array}{l}\text { Male } \\
(\%)\end{array}$ \\
\hline Clinical \& Health Psychology & 5629 & 51.7 & 83.3 & 16.7 \\
\hline Educational Psychology & 2357 & 21.6 & 88.6 & 11.4 \\
\hline $\begin{array}{l}\text { Work \& Organizational } \\
\text { Psychology }\end{array}$ & 913 & 8.4 & 76 & 24 \\
\hline $\begin{array}{l}\text { Social \& Community } \\
\text { Psychology }\end{array}$ & 983 & 9 & 87.5 & 12.5 \\
\hline Forensic Psychology & 225 & 2.1 & 85.0 & 15 \\
\hline Sports Psychology & 26 & 0.23 & 34.8 & 65.2 \\
\hline Gerontology & 36 & 0.32 & 91.2 & 8.8 \\
\hline University & 474 & 4.4 & 72.4 & 27.6 \\
\hline Others & 16.5 & 0.15 & 87.1 & 12.9 \\
\hline
\end{tabular}

Source: own source

The results of the distribution by fields in each delegation follow the national trend of distribution. However, there are some exceptions; in the south area there are higher percentages of psychologists in the clinical and health $(59.5 \%)$ and work and organizational $(10.4 \%)$ fields but less educational psychologists (18.1\%). The central region presents a lower percentage of psychologists working in the field of work and organizational psychology (6.6\%), while the autonomous region of Madeira presents a very low percentage of psychologists working in that area $(3.1 \%)$. It is, however, in the autonomous region of the Azores where the most dissimilar results can be found: low percentage of psychologists in the field work and organizational psychology and higher percentages, than the national averages, in social and community field (20.0\%) and forensic psychology $(5.6 \%)$.

There are some psychologists who report working in more than one area of Psychology, a specific situation concerns psychologists who work at the Universities, since they can teach and/or do some scientific research. Out of a total of 474 psychologists who are working in universities, 108 claimed to be solely researchers and almost half of psychologists that 
teach also do some scientific research (40.1\%). However it is psychologists who claimed to work in Clinical and Health Psychology that are more likly to work in other areas of Psychology, as 253 (27.7\%) psychologists work additionally in Educational Psychology; 168 (18.4\%) in Teaching; 79 (8.6\%) in Work and Organizational Psychology; and $46(5 \%)$ in Social \& Community Psychology.

\section{Type of Work Center}

Portuguese psychologists work mainly in private practice $(57 \%)$ which includes individual private practice, associations, nongovernmental organizations (NGOs), and companies. Public centers (38\%) include hospitals, schools, and governmental departments. Only 5\% of OPP's members claim to be unemployed (or retired). The number of psychologists who reported working outside Portugal or working with a scholarship is minimal.

In table 2 the first two columns present the distribution of work by sector.

\section{Table 2}

Percentage of Psychologists Working in each Field by Work Sector

\begin{tabular}{lllll}
\hline $\begin{array}{l}\text { Public } \\
(\%)\end{array}$ & $\begin{array}{l}\text { Private } \\
(\%)\end{array}$ & & $\begin{array}{l}\text { Public } \\
(\%)\end{array}$ & $\begin{array}{l}\text { Private } \\
(\%)\end{array}$ \\
\hline 33.7 & 66.3 & Clinical \& Health Psychology & 45.2 & 59.9 \\
55 & 45 & Educational Pychology & 31.3 & 17.2 \\
21.3 & 78.7 & Work \& Organizational Psychology & 4.6 & 11.4 \\
37.5 & 62.5 & Social \& Community Psychology & 8.7 & 9.7 \\
64.3 & 35.7 & Forensic Psychology & 3.5 & 1.3 \\
24.1 & 75.9 & Sports Psychology & 0.2 & 0.4 \\
8.6 & 91.5 & Gerontology & 0.1 & 0.5 \\
57.2 & 42.8 & University & 6.4 & 3.2 \\
54.4 & 45.6 & Others & 5.5 & 3.1 \\
\hline \multicolumn{2}{r}{ Total } & 100 & 100 \\
\hline
\end{tabular}

Source: own work

It is possible to observe that psychologists in Clinical and Health, Work and Organizational, Social and Community, Sports, and Gerontology Psychology work mainly in the private sector. The remaining areas (Educational, Forensic, and University as well as other fields) have more expressive results for public work center.

The two columns to the right express how the professionals are distributed by fields of work according to public and private sectors. In both sectors, Clinical and Health Psychology is the dominant area; however, it is in the private sector that the predominance of Clinical and Health Psychology is more noticeable. It is also worthy of note that Educational Psychology is clearly the second area with most psychologists, but only in the public sector.

As mentioned before, Portuguese psychologists work mostly in private practice (from $58.4 \%$ in the North to $63 \%$ in the South). This tendency is reproduced all over the country with one exception: Madeira where $79.9 \%$ of psychologists work in public centers.

\section{Unemployment}

The number of unemployed psychologists, as reported by the Institute of Employment and Professional Training (IEFP), has increased steadily since September 2009, from 2489 to 4472 (a $79.6 \%$ increase). Although only $5 \%$ of OPP's registered members state that they are not working as psychologists, this number is significantly higher.

\section{Psychology University Training in Portugal}

In 2012 there were 26902 holders of a psychology university degree that would allow them entry into the Order. As it can be seen in Figure 1, the number of psychology graduates has risen dramatically since the year 2001. In 12 years (2000-2012), the number of psychology graduates has almost quadrupled. It is important to highlight that, in this period, the mean of graduates in psychology is 1590 , which means that each of these years presents as many graduates as the whole 1991-1995 period. 


\section{Figure 1}

Number of Graduates since 1990 to 2012.

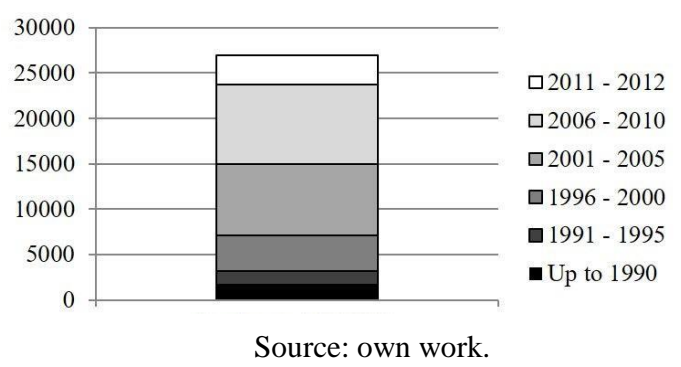

Analyzing the number of students who are finishing their degree per year, the number has remained consistently high, above 1500 graduates per year (Figure 2). This means that every 6 years, Portugal is forming enough graduates to produce 1 psychologist per 1000 inhabitants.

\section{Figure 2}

Graduates in Psychology Annually since 2001.

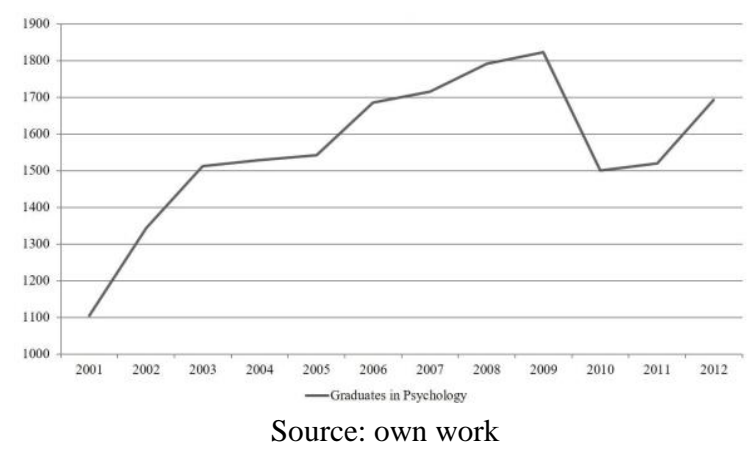

The number of Portuguese psychology students has increased sharply since 1995, when there were 5522 students. In the year of 2000 this number had almost doubled to 10002 students, and it reached a peak in 2005 with 12726 psychology students. After the full implementation of the Bologna process, in 2010, the number of psychology students was 11663 . The most recent figures from official sources (Direcção-Geral de Estatísticas da Educação e Ciência [DGEEC], 2013b) place the number of psychology students in 2012 at 10992, which means an increase of $99.1 \%$ over 1995 .

It is important to notice that the number of students in a second cycle of psychology has increased by $7.4 \%$, despite the economic crisis the country is experiencing. Since the academic year 2008/09 this number has grown from 4078 to 4378 students in 2010/11; this contrasts with the number of total graduates in Portugal, which has been decreasing since 2007/08 (DGEEC, 2013a). After the Bologna process, a second cycle of studies in Psychology is a requirement for exercising the profession of psychology.

\section{Figure 3}

Number of Degrees since 1980 to 2013 in Portugal.

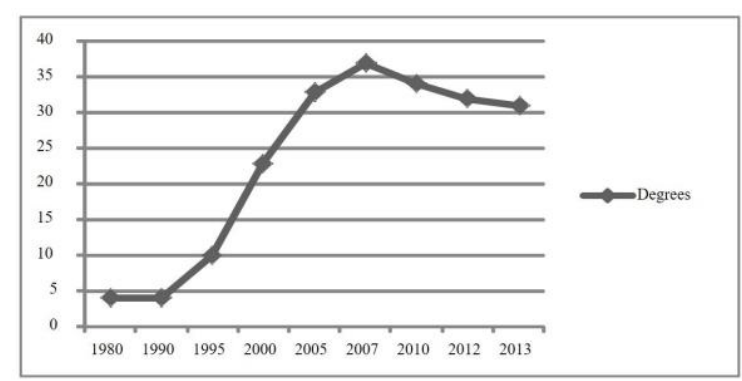

Source: Own work.

As it can be seen in figure 3, the number of psychology degrees in Portuguese Universities had grown until 2007. Presently, there are 31 degrees in Psychology in Portugal. More than half of the students who finish a 2nd cycle of studies in psychology do so in Clinical/ Health Psychology (56.6\%). Work/Organizational together with Social and Community Psychology are responsible for $14.9 \%$ of the graduates, while Educational Psychology accounts for $12.1 \%$. The 4th area with most graduates in Psychology is Forensic Psychology with $10.4 \%$.

\section{Conclusions}

The last two decades have clearly changed the face of profession of psychology in Portugal. The number of people who hold a psychology university degree has grown immensely; there are 13 times more psychology degree holders in 2012 then there were in 1990, as well as almost a threefold increase since 2000. There is an active psychologist per 742 Portuguese, which situates Portugal well above the countries analyzed. Looking to the number of people who 
Vitor Alexandre Coelho, Marta Marchante, Patrícia Brás, Liliana Pereira.

are finishing Psychology degrees yearly, this number is likely to continue to increase.

The development in Portugal followed a similar pattern to the Spanish one, even though in this country this growth started 10 years earlier and has reduced since. Presently, the ratio of psychologists per inhabitant is already lower in Portugal than in Spain $(1=831)$, placing Portugal as the country with the highest number of psychologists per inhabitant. Portugal presents a ratio than less than half of another European country of similar population Belgium $(1=1538)$.

The ratio of psychologists in bigger countries where the profession has been established much earlier is quite lower. The United States of America, Germany, or United Kingdom presented ratios of psychologists per inhabitants of $1=3333 ; 1=1514$, and $1=1522$ respectively. It is interesting to notice that Spain presents a higher number of psychologists than Germany and the UK, even though it has a much smaller population $(46.5,80.5$, and 64 million, respectively).

In Portugal, this period of rapid growth of people who possess a university degree in Psychology is set to continue since international comparisons place Portugal at the top of university degrees in Psychology per million inhabitants, Portugal presently has 31 university degrees (2.96/million inhabitants), more than Spain (a country with 4 times more population) that presents 30 university degrees (0.65/ million inhabitants); a country with similar population (Belgium) has 7 university degrees in Psychology (0.64/million inhabitants). The ratio of university degrees per million inhabitants in the USA (1.44), in the UK (1.80 for 1 st cycle studies), and in Germany (0.55) is also quite lower than in Portugal.

Naturally, this period of growth has drastically altered the profession of Psychology in Portugal. As such, presently, the professional situation of psychologists in Portugal is marked by the high levels of unemployment as well as a strong competition to enter the labor market. Due to this competition, it is worth mentioning that a significant part of those who finish a psychology university degree do not apply for the title of psychologist. Also, the economic crisis (and the subsequent failure to pay tuition fees), drop out, unemployment, or school failure may be responsible for the fact that, although the number of students attending the second study cycle has increased, there is a big discrepancy between that number and the number of graduates.

There is also a discrepancy in unemployment rates between OPP's and IEFP's data due to suspended membership or non-registration of member trainees. This makes the IEFP data about unemployment more reliable. According to data reported by the IEFP, almost 1/5 of psychology graduates are unemployed; this number is higher than the national unemployment rate $(16.9 \%$, December 2012). Additionally, this rate is also higher than the national unemployment rate for graduates $(13.3 \%)$. Comparing with other professions, according to data reported by IEFP, the unemployment rate for teachers is closer to $1 / 6$, with teachers being an example of a profession that works typically for the public sector. Alternatively, the Architect Society, made up of professionals that usually work in private practice, report similar results (Borges, 2006).

In fact, the last three years the professional situation of psychologists in Portugal has been marked by a fast increase in unemployment. The levels of unemployment in Portugal are not dissimilar to those reported in Spain, where in October 2013 there were 17046 unemployed psychologists (Servicio Público de Empleo Estatal: 30.4\%). In Spain the national unemployment percentage at that date was $26 \%$, however, these figures are dismal when compared with the practical inexistence of unemployment among psychologists in Germany (Spinath \& Stehle, 2010).

Regarding fields of practice, the data presented in this study allow us to conclude that most Portuguese psychologist work in Clinical/Health Psychology (which is common among European countries; $68.4 \%$ in Spain and $55 \%$ in Germany) and almost a quarter of them claim to be Educational Psychologists (higher than in Spain that with $15.3 \%$ already had a very high percentage of practitioners in 
this field, while Germany presents just $4 \%$ of psychologists and the United States 2.6\%). It is also among psychologist who mainly work in Clinical/Health Psychology that there is the biggest number of psychologists that work in other areas of Psychology simultaneously. Also, there are more people studying Clinical/Health Psychology than those who report that are working in this area. This discrepancy may result from "mixed-fields" (59.8\% of clinical/ health psychologists that work in other fields) and the overlap between areas, for example, there is a great number of educational psychologists with a clinical/health background. This means that many of those who hold a pre-specialization in Clinical Psychology sometimes are working partially or fully in other areas. This also explains the apparent discrepancy between the number of educational professionals and students.

The results of the forensic psychology area are surprising, considering the national average of practitioners $(2.1 \%)$, the percentage of graduates in this field is fivefold superior in 2010 (10.4\%). This means that is still difficult to predict the importance that this field will have, since this is a field with very different weight in different countries; in Germany it is responsible for $5 \%$ of practitioners, while Spain only report $1.2 \%$, and in the USA only $0.7 \%$ practice in the forensic context (APA, 2014b).

The profession in Portugal is marked by a disproportion between male and female psychologists, higher than in other European countries, such as Spain. The predominance of female psychologists is noticeable in all areas of the profession and is not unusual in other areas of the Social and Health Sciences, which also reveal a clear "feminization" process. According to Portugal in Figures 2012 (Instituto Nacional de Estatística, 2012), "women represented the majority of the tertiary education population in the school year 2011/2012, and in graduates (60.4 women in every 100 graduates)".

The majority of psychologists work in the private sector, even though this prevalence is not as high as the one reported in Spain, where $73 \%$ of psychologists work in private centers (Santolaya et al., 2001). The exception is the region in Madeira, where the oppostie prevalence stems from the fact that the regional government invested greatly in the recruitment of psychologists for public services (hospitals, schools, and city councils), since Madeira was a traditionally poorer area, where tourism is the most profitable activity.

It can be also concluded that psychologists in Portugal have: a) versatility and flexibility; b) mostly jobs of a precarious nature. Many psychologists cannot get a full time job in Psychology, with some seeking other employment to complete schedule or opportunities in other areas. Also, it is safe to assume that the number of people holding a license degree in Portugal will continue to grow, as Portugal still has a very big number of institutions where Psychology is taught. This recent development means that most of the professionals are both quite young and inexperienced, creating a scenario that presents both challenges and opportunities (e.g. more psychological research, more social recognition, more opportunities to contribute to well being, etc.), but mostly problems (e.g. unemployment, underpayment, excess of unpaid "internships", different qualifications standards, lack of adequate supervision, etc.).

In synthesis, presently the main issues for Portuguese psychologists are employability and mobility, especially with the increase in unemployment. As more people finish up their university training in Psychology competition for jobs increases and many have formulated interested in applying their psychology training outside of Portugal.

\section{References}

Aparicio-García, M. E., \& Sánchez-López, M. P. (2010). Teaching Psychology in Spain. In Europlat (Ed.), Europlat annual conference 2010: Partner poster submissions (p. 33). York, UK: University of York.

American Psychological Association, Center for Workforce Studies. (2014a, June). How many practicing psychologists are 
Vitor Alexandre Coelho, Marta Marchante, Patrícia Brás, Liliana Pereira.

there in the United States? Retrieved from https://www.apa.org/support/about/p sych/numbers-us.aspx\#answer

American Psychological Association, Center for Workforce Studies. (2014b). APA member profile. Retrieved from http://www.apa.org/workforce/public ations/13-member/index.aspx

Belgian Psychologist Commission. (2011). Jaarverslag 2011 versie 2 (Annual Report 2011 Version 2). Retrieved from www.co mpsy.be/overons/jaarverslagen

Borges, V. (2006). Relatório Profissão: Arquitecto/a (Profession Report: Architect). Unpublished manuscript, Instituto de Ciências Sociais, Universidade de Lisboa, Lisboa, Portugal.

Cardoso, J. L., Varanda, M., Madruga, P., Escária, V., \& Ferreira, V. S. (2012). Empregabilidade e ensino superior em Portugal [Employability and university studies in Portugal]. Lisboa: Instituto de Ciências Sociais.

Coelho, V., \& Ribeiro, G. (2001). Um país de psicólogos [A country of psychologists]. Revista Universitária de Psicologia, 1 , 5-8.

Coelho, V., Brás, P., \& Sousa, V. (2011, July). A country of psychologists?: Portugal as a case study. Poster presentation at the 12th European Congress of Psychology, Istanbul.

Direcção-Geral de Estatísticas da Educação e Ciência. (2013a). Diplomados (1995/1996 a 2011/2012) [Graduates (1995/1996 to 2011/2012)]. Retrieved from http://www.d geec.mec.pt/np4/EstatVagasInsc/

Direcção-Geral de Estatísticas da Educação e Ciência. (2013b). Vagas (1995/1996 a 2012/2013) [Vacancies (1995/1996 to 2012/2013)]. Retrieved from http://www.d geec.mec.pt/np4/EstatVagasInsc/

European Federation of Psychologists' Associations. (2013a). EuroPsy - the European Certificate in Psychology. Retrieved from http://www.europsy-efpa.e u/sites/default/files/uploads/EuroPsy\%20 Regulations\%20July\%202013.pdf
European Federation of Psychologists' Associations. (2013b). Report 2013 of the task force resources (Report presented at EFPA General Assembly). Retrieved from http://www.efpa.eu/reports/reports-g eneral-assembly-2013

Hernández Gordillo, A. (2003). Los estudios universitarios de Psicología en España: Evolución de centros, alumnos y relación oferta-demanda [Psychology University Degrees in Spain: Evolution of institution, students and supply-demand ratio]. Papeles del Psicólogo, 24 (86), 13-24.

Instituto Nacional de Estatística. (2012). Portugal in figures 2012 . Retrieved from http://www.ine.pt/xportal/xmain?xpi $\mathrm{d}=$ INE\&xpgid=ine_publicacoes\&PUBLIC ACOESpub_boui=214351093\&PUBLIC ACOEStema $=00 \&$ PUBLICACOESmodo $=2$

Roe, R., \& Freeman, R. (2011). 30 years of EFPA: Past, present and future. European Psychologist, 16 , 83-89. http://dx.doi.org/ 10.1027/1016-9040/a000084

Santolaya Ochando, F., Berdullas Temes, M., \& Fernández Hermida, J. R. (2001). The decade 1989-1998 in Spanish Psychology: An analysis of development of professional psychology in Spain. The Spanish Journal of Psychology, 4 , 237-252. http://dx.doi.or $\mathrm{g} / 10.1017 / \mathrm{S} 1138741600005771$

Spinath, B., \& Stehle, S. (2010). Studying psychology in Germany. Teaching psychology in Spain. In Europlat (Ed.), Europlat annual conference 2010: Partner poster submissions (p. 33). York, UK: University of York.

Trapp, A., \& Reddy, P. (2010). Teaching psychology in United Kingdom. In Europlat (Ed.), Europlat annual conference 2010: Partner poster submissions (p. 33). York, UK: University of York.

United States Census Bureau. (2010). Redistricting data . Retrieved from http://www.census.gov/2010census/data/

Wicherski, M., Hamp, A., Christidis, P., \& Stamm, K. (2014). 2013-14: Faculty salaries in graduate 
departments of psychology . Retrieved from http://www.apa.org/workforce/public ations/13-fac-sal/index.aspx

\section{Notes}

* Research article 